UDK 81'272: 314.742(417=163.42) Izvorni znanstveni rad Primljeno 27. prosinca 2019. DOI: $10.38003 /$ zrffs. 13.8

\author{
Sanja Škifić \\ Sveučilište u Zadru, Odjel za anglistiku \\ HR-23000 Zadar, Obala kralja Petra Krešimira IV/2 \\ sskific@unizd.hr \\ Katarina Grbas \\ HR-23000 Zadar, Dubrovačka ulica 32A \\ grbaskatarina@gmail.com
}

\title{
JEZIČNA UPORABA I STAVOVI HRVATSKIH IMIGRANATA U IRSKOJ
}

\begin{abstract}
Sažetak
Imigracija u Irskoj, uključujući imigraciju Hrvata u tu zemlju, u posljednje vrijeme u znatnom je porastu. Stoga Irska u posljednjih nekoliko godina nastoji pronaći načine na koje se imigrantima može osigurati odgovarajuća kulturna i jezična integracija u irsko društvo. Ovaj rad se bavi istraživanjem jezične uporabe i stavova hrvatskih imigranata u Irskoj. U istraživanju koje je provedeno od lipnja do kolovoza 2019. godine sudjelovala su 82 hrvatska imigranta u Irskoj. Za potrebe istraživanja korišten je upitnik koji se sastojao od četiriju dijelova i koji su ispitanici ispunjavali preko društvene mreže Facebook. Od ispitanika se tražilo da odgovore na pitanja vezana za vlastito iskustvo emigracije u Irsku, a većina jezičnih pitanja odnosila se na engleski, i to na pojedine aspekte učenja, razine poznavanja i uporabe engleskoga jezika u različitim kontekstima. Rezultati istraživanja pokazuju, između ostaloga, da većina ispitanika ima pozitivan stav prema boravku u Irskoj te engleskome jeziku. Većina njih procijenila je svoju trenutačnu razinu znanja engleskoga jezika mnogo boljom od prosjeka. Iako znanje engleskoga jezika većinom nije procijenjeno ključnim za pronalazak posla u Irskoj, ipak ga je značajan broj ispitanika procijenio bitnim prilikom njihova zaposlenja.
\end{abstract}

Ključne riječi: imigracijska politika, jezična politika, jezična uporaba, jezični stavovi, hrvatski imigranti, Irska, engleski jezik

\section{Uvod}

Sociolingvistički konteksti u kojima je engleski većinski jezik nerijetko su obilježeni specifičnim povijesnim prilikama, poput onih koje uključuju kolonizaciju i migraciju i koje su uzročno-posljedično vezane uz političko-ekonomske čimbenike. Jedno od obilježja višejezičnih država u kojima je engleski većinski jezik jest i značajan broj manjinskih zajednica i jezika. Pitanja vezana za status manjinskih jezika i njihovu uporabu svakim su danom sve relevantnija, posebice u odnosu na trenutačni status engleskoga jezika te ono što Maurais i Morris (2003: 1) opisuju koristeći izraz 
„nadmetanje jezika.“ ${ }^{1}$ S obzirom na njegov status, uloga engleskoga jezika u posljednje vrijeme sve češće se razmatra u analizama jezičnih politika raznih zemalja te u odnosu na ekonomski razvoj, neoliberalizam te mogućnosti zapošljavanja (v. Ricento 2018). Analiza sprege između društveno-kulturološkoga te jezičnog aspekta u recentnim sociolingvističkim istraživanjima u značajnoj mjeri usmjerena je upravo na jezičnu uporabu i stavove pripadnika manjinskih zajednica koje su nastale kao posljedica raznih migracija. Ovaj se rad bavi istraživanjem jezične uporabe i stavova među hrvatskim imigrantima u Irskoj. Osnovni je cilj rada utvrditi u kojoj mjeri hrvatski imigranti rabe engleski jezik te istražiti njihove stavove prema engleskom i materinskom jeziku te boravku u Irskoj. S obzirom na činjenicu da stavovi prema jeziku imaju određenu ulogu u mjeri jezične uporabe, opažanje i tumačenje jezičnih stavova iznimno su važni u ovakvoj vrsti istraživanja. Povezanost jezičnih stavova i uporabe evidentna je u raspravama o ugroženim (autohtonim) jezicima, ali i u raspravama o drugim manjinskim jezicima čija se uporaba na nekom prostoru javlja kao posljedica različitih migracija. Važnost istraživanja migracijskih procesa sa sociolingvističkog stajališta potvrđuje činjenica da se, osim pomicanja nacionalnih granica, kretanja naroda smatraju jednim od najznačajnijih ishodišta tzv. društvene dvojezičnosti (v. Sebba 2011: 447-448).

Kao mnogi drugi europski narodi, i Hrvati su u pojedinim povijesnim razdobljima emigrirali u značajnijem broju na razne kontinente i u različite države. Uzroci tome mogu se, kao i kod migracija ostalih naroda, tražiti u povijesnim, političkim i/ili ekonomskim čimbenicima. U radu koji se na temelju etnološkei kulturnoantropološke metodologije bavi određenim pitanjima suvremenog iseljavanja iz Hrvatske u Irsku s naglaskom na mlade iseljenike iz Slavonije, Rajković Iveta i Horvatin (2017: 248) kao polaznu točku navode zamjetnu medijsku pozornost posvećenu takvoj vrsti iseljavanja. Nadahnuće za ovaj rad djelomično je također povezano s različitim oblicima medijske prisutnosti navedene tematike. Međutim, temi se u ovome radu pristupa sa sociolingvističkog stajališta, pri čemu je naglasak stavljen ponajprije na jezičnu uporabu i stavove hrvatskih imigranata u Irskoj.

S ciljem uspostave što jasnije korelacije između jezične uporabe i stavova među Hrvatima u Irskoj, u radu je dan osvrt na irsku imigracijsku politiku te na hrvatsku emigraciju u Irsku, koja je u posljednjih nekoliko godina u znatnom porastu. Analizi podataka prikupljenih tijekom istraživanja prethodi i uvid u irsku jezičnu politiku te stavove Hrvata prema engleskome jeziku.

\section{Irska imigracijska politika i hrvatska emigracija u Irskoj}

Imigracijske politike zemalja oblikovane su pod utjecajem različitih čimbenika, a dijakronijska analiza takvih politika otkriva da su podložne promjenama. Jačanje zahtjeva za priznavanje različitosti postaje izraženije s jačanjem globalizacijskih trendova (Zlatković Winter 2001: 41), i to u većini europskih i neeuropskih država, neovisno o povijesnom intenzitetu imigracije te sukladno sve bržim i učinkovitijim načinima komunikacije i kretanja ljudi. S obzirom na to da u posljednje vrijeme raste broj imigranata u Irskoj, postavlja se pitanje razvoja irske integracijske politike. U analizi poteškoća u integraciji te uvažavanju kulturoloških razlika manjinskih

1 Eng. language competition. 
zajednica, Ross-Lonergan (2009: 338) navodi da je irska imigracijska politika određena tržištem rada, a zakonski okvir neodređen u definiranju konkretnih oblika pomoći koje bi imigranti trebali imati na raspolaganju. S. Garner (2004), autor jednog od ključnih radova za razumijevanje odnosa irskog identiteta te nacionalizma i rasizma, važnima u razumijevanju toga odnosa smatra iskustva vezana za Britansko Carstvo, ali i irsku imigraciju u 19. stoljeću.

Na Garnera (2004) u tumačenju procesa prihvaćanja i razvoja ideje različitosti vezanog za suvremeni porast migranata u Irskoj referira se i Ross-Lonergan (2009: 337-338), i to u dijelu gdje Garner (2004: 208) povezuje stvaranje vizije moderne Irske s politikom nacionalizma, a sukladno viziji gelskog, ruralnog, katoličkog i sjedilačkog načina života. S druge, šire političke strane, u analizi prijelaza od nacionalizma do postnacionalizma, Böss (2010: 17-18) povezuje trenutačni identitet Irske s pojmom neutralnosti, a jačanje takve percepcije dovodi u vezu upravo sa slabljenjem vizije gelske i katoličke Irske početkom 1960-ih. U drugoj polovici 20. stoljeća za irski identitet bitan je i ulazak u Europsku uniju. Irska je postala članicom Europske unije 1973. godine, a Hayward (2009) ističe važnost ulaska Irske u Europsku uniju u analizi odnosa između irskog nacionalizma i europske integracije. S druge strane, sama integracija imigranata u Irskoj ovisi ponajprije o irskoj imigracijskoj i integracijskoj politici, pri čemu ne treba zanemariti stajališta i djelovanja samih imigranata. Različiti prilozi u Lentin i Moreo (2012) svjedoče upravo o pojedinim aspektima tzv. „migrantskog aktivizma“ u procesima integracije u Irskoj.

Unatoč uočenim poteškoćama u osmišljavanju vizije integracije, u posljednjih nekoliko godina javljaju se konkretni okviri koji upućuju na to da Irska nastoji osmisliti način odgovarajuće integracije imigranata u svoje društvo. Naime, u veljači 2017. godine objavljena je Strategija integracije imigranata (The Migrant Integration Strategy) koja se odnosi na razdoblje od 2017. do 2020. godine. Strategija uključuje niz aktivnosti od kojih se sljedeće odnose na sve vladine sektore, a to su osiguravanje: informacija imigrantima u jezično-prikladnim formatima, trajne obuke službenika o interkulturnom osvješćivanju, znakovlja u javnim uredima koja upućuju na mjesta gdje se može dobiti usluga prevođenja te informacija o tome kako uložiti žalbu zbog rasističkog ponašanja službenika ili drugog klijenta (4). ${ }^{2}$

0 imigracijskim i jezičnim politikama, osim u relevantnim znanstvenim publikacijama, može se saznati i uvidom u trenutačne uvjete koje država postavlja pred podnositelje zahtjeva za naturalizaciju. Na mrežnim stranicama Irske službe za naturalizaciju i imigraciju [Irish Naturalisation and Immigration Service (INIS)] navedeni su uvjeti pod kojim osoba može podnijeti zahtjev za naturalizaciju, a iz kojih je vidljivo da, za razliku od niza drugih država (Usp. Škifić 2013.), i to ne samo dominantno anglofonih, ${ }^{3}$ Irska ne postavlja poznavanje jezika kao jedan od uvjeta za stjecanje državljanstva naturalizacijom.

Povijesno gledano, Hrvati su, ovisno o razdoblju, emigrirali u razne europske i neeuropske države, a razloge tome treba tražiti u tipičnim razlozima većine

20 jezičnim pitanjima u dokumentu će više riječi biti u dijelu rada koji se bavi irskom jezičnom politikom.

3 Primjerice, jezični preduvjet (poznavanje hrvatskoga jezika i latiničnoga pisma) postavlja se i pred osobe koje se prijavljuju za hrvatsko državljanstvo putem naturalizacije, odnosno prirođenja. V. čl. 8. st. 4. Zakona o hrvatskom državljanstvu iz 1991. godine. 
emigracija - ekonomskim, gospodarskim i/ili političkim čimbenicima. U posljednje vrijeme sve veća pozornost posvećuje se opisima imigracija Hrvata u europske zemlje, s posebnim osvrtom na migrantsku skupinu koja se naziva „odljevom mozgova“ i koja "predstavlja prema obujmu, a još više prema strukturalnim kvalitativnim značajkama, prevladavajuću mirnodopsku i gospodarsku emigraciju novijeg razdoblja« (Lajić 2004: 179). Navedeni trend bio je vidljiv u prvom, a nastavlja se i u drugom desetljeću 21. stoljeća. Hrvatska je postala članicom Europske unije u srpnju 2013. godine, što je, između ostaloga, doprinijelo većem kretanju hrvatskoga stanovništva u ostale države članice Europske unije. To potvrđuju i Rajković Iveta i Horvatin (2017: 255), koje na temelju podataka preuzetih sa službene mrežne stranice irskoga Vladina ureda za zapošljavanje i socijalnu zaštitu zaključuju »da se broj hrvatskih državljana koji su otišli živjeti u Irsku nakon ulaska Republike Hrvatske u Europsku uniju (1. srpnja 2013.) u samo jednoj godini povećao četiri puta (2014.) i da od tada kontinuirano raste«. Autorice na temelju prikupljenih podataka identificiraju različite razloge emigracije mladih iz Hrvatske, od kojih su najistaknutiji ekonomski razlozi, te razloge emigracije mladih Hrvata upravo u Irsku, od kojih se ističu poznavanje engleskoga jezika, otvorenost tržišta rada, jednostavnost birokratskog sustava vezanoga za život i posao imigranata u Irskoj te prihvatljiva udaljenost (Rajković Iveta i Horvatin 2017: 264-268). U ovome radu usredotočit ćemo se upravo na jezični aspekt, odnosno na samu jezičnu uporabu i stavove hrvatskih imigranata u Irskoj.

\section{Irska jezična politika}

Jezične politike nerijetko se grade, mijenjaju i, naposljetku, procjenjuju, ovisno o poimanju nacionalnosti u određenoj državi, odnosno na određenome prostoru. Kamusella (2018: 176) navodi da za razliku od situacije u središnjoj Europi, važnost jezika za pojedina nacionalna i državna pitanja u većini država zapadne Europe, za koje navodi da su dominantno neizomorfne, ${ }^{4}$ nije toliko velika. Iako je Irska dio zapadne Europe, postavlja se pitanje u kojoj ju je mjeri prema navedenome kriteriju moguće svrstati u većinu država zapadne Europe. I prije samoga uvida u aspekte irske jezične politike, na temelju dijakronijske analize razvoja same države, može se ustvrditi da su, između niza povijesnih događaja, ponajprije napetost i previranja u odnosima s Velikom Britanijom imali najveću ulogu u oblikovanju irske jezične politike. Pritom su povezanost nacionalnoga identiteta i irskog jezika te specifično viđenje engleskoga jezika njezina najbitnija obilježja.

Crowley (2000: 1) uspoređuje povijesnu složenost odnosa Irske i Engleske sa složenosti odnosa dvaju glavnih jezika u Irskoj, a to i ilustrira navođenjem niza obilježja koja se pripisuju irskom i engleskom jeziku, od kojih su neka: irski - jezik duše, jamac „irskosti, ${ }^{\text {“5 }}$ jezik filozofije, jezik prošlosti, nacionalni jezik; engleski kolonijalni jezik, jezik poezije, jezik suvremenosti, jezik svakodnevne trgovine, jedini jezik koji rabe irski emigranti. Određivanje engleskoga jezika kao jedinoga jezika koji rabe irski emigranti iznimno je bitno, a, iako Crowley (2000) ne navodi da je i kod

4 Kamusella (2018: 173) raspravlja o normativnom izomorfizmu jezika, nacije i države, odnosno o uskom prostornom i ideološkom preklapanju navedenih triju elementa.

5 Eng. Irishness. 
imigracije u Irsku moguće identificirati isto obilježje engleskoga jezika, razvidno je da to vrijedi i u tome slučaju. Stoga se u ovome radu koji se bavi istraživanjem jezične uporabe i stavova hrvatskih imigranata u Irskoj usredotočujemo prije svega na engleski jezik, iako se daje osvrt i na hrvatski jezik.

Razni pokušaji potiskivanja irskoga jezika te borbe za njegovo očuvanje također imaju dugu povijest. Stoga ne čudi zašto je veliki dio irske jezične politike usmjeren upravo na određivanje odnosa dvaju službenih jezika - irskog i engleskog. Moriarty (2015) raspravlja o važnosti uloge koju globalizacija ima u razvoju jezične politike i planiranja te, konkretno, u procesima revitalizacije jezika vezano uz određenje statusa irskoga jezika između manjinskoga i ugroženoga jezika. Nakon analize povijesnoga konteksta obilježenog nastojanjima očuvanja irskoga jezika (s posebnim osvrtom na Gaeltacht), ${ }^{6}$ Mac Giolla Chríost (2008) navodi pozitivne inicijative u jezičnom planiranju irskoga na makrorazini početkom 21 . stoljeća ${ }^{7}$ te ističe potrebu djelovanja na mikrorazini da bi očuvanje irskoga jezika bilo što učinkovitije.

S obzirom na povijesni i politički kontekst unutar kojega se razvijala irska jezična politika, razumljivo je zašto je, u odnosu na već opisano, literatura o irskoj jezičnoj politici prema imigrantima znatno oskudnija. Stoga se u ovome dijelu rada oslanjamo ponajprije na relevantan dokument na temelju kojega je moguće donositi zaključke i o tome aspektu suvremene irske jezične politike.

Strategija integracije imigranata (2017) sadrži niz jezično relevantnih okvira. U prethodnome dijelu rada izdvojene su aktivnosti navedene u Strategiji koje se odnose na sve vladine sektore i kod kojih je značajan naglasak stavljen na pružanje pomoći imigrantima u razumijevanju informacija. Osim tih, navodi se i niz konkretnih aktivnosti, od kojih je jezično relevantna sljedeća: uključivanje jezične komponente u programe obrazovanja i obuke za nezaposlene imigrante s lošim poznavanjem engleskoga jezika (5). U uvodnome dijelu Strategije navode se dosadašnji uspjesi, ali i pitanja koja su još uvijek prepreka integraciji, od kojih se prvi navedeni odnosi na ovladavanje jezikom, posebice za one koji su nedavno došli u Irsku (7). Vizija Strategije uključuje dvanaest točaka, od kojih se četvrta odnosi na jezične vještine koje će imigrantima osigurati sudjelovanje u ekonomskom životu i širem društvu (10). Unutar općih planiranih aktivnosti navodi se omogućivanje pristupa migranata dokumentima iz kojih mogu učiti o Irskoj, njezinoj povijesti, kulturi i sličnom, a koji će biti u prikladnom formatu i na različitim jezicima (21). U dijelu vezanome za državljanstvo, planirana aktivnost je i razmatranje uvođenja provjere znanja o građanskim pravima i dužnostima te provjere poznavanja engleskoga jezika (23). U dijelu osiguravanja pristupa javnim službama i društvene uključenosti opet se navodi pružanje informacija u lako dostupnim jezično prikladnim formatima te dostupnost tumačenja/prijevoda na različitim jezicima koja će biti oglašena u relevantnim javnim uredima (23-24). Najveći broj jezično relevantnih aktivnosti naveden je u području obrazovanja, primjerice: praćenje broja školske djece migranata koja ne govore engleski, razmatranje organiziranja $\mathrm{ESOL}^{8}$ obuke za odrasle pripadnike etničkih manjina, praćenje primjerenosti jezične potpore u školama za djecu

6 Izraz "Gaeltacht" označava irsko govorno područje.

7 Ističe se tzv. Official Languages Act iz 2003. godine, zakonski okvir koji je vezan za poboljšavanje pružanja javnih usluga na irskome jeziku (Mac Giolla Chríost 2008: 83).

8 English for Speakers of Other Languages. 
pripadnike etničkih manjina, njegovanje pozitivnih stavova prema različitosti koje će i dalje biti dio školskoga kurikula, organiziranje naknadnih ESOL programa za imigrante da bi ovladali naprednijim jezičnim vještinama i uspješnije se integrirali na radnome mjestu (25-26). Naglasak je na jezičnu komponentu stavljen i u dijelu aktivnosti vezanih za zapošljavanje imigranata, prije svega uključivanjem jezične komponente u određene programe obrazovanja ili obuke za migrante (27).

Imigracijske politike u uskoj su vezi s jezičnim politikama, a uvid u jezične preduvjete koje pojedinci moraju ispuniti u procesima naturalizacije u određenoj zemlji otkrivaju obilježja njezine jezične politike. Za razliku od većine dominantno anglofonih zemalja poput SAD-a, Kanade, Australije i Novoga Zelanda, u kojima je u procesima naturalizacije na različite načine naglašeno poznavanje engleskoga jezika (Škifić 2013), pri podnošenju zahtjeva za stjecanje irskoga državljanstva na službenim stranicama INIS-a ne spominju se jezični preduvjeti. Međutim, u Strategiji integracije imigranata (2017) naznačena je mogućnost uvođenja provjere poznavanja engleskoga jezika u postupku stjecanja državljanstva, što također govori o postojanju naznaka mogućih budućih promjena u irskoj imigracijskoj i jezičnoj politici.

\section{Stavovi Hrvata prema engleskome jeziku}

Postoje različite vrste jezičnih stavova, a u središtu zanimanja ovoga rada dvije su vrste koje Baker i Prys Jones (1998) određuju kao stavove prema manjinskom ili većinskom jeziku te stavove prema učenju drugoga (stranoga) jezika. U potonjoj skupini možemo razlikovati integrativne (vezane uz želju za poistovjećivanjem s drugom jezičnom skupinom ili uklapanjem u drugu jezičnu skupinu) te instrumentalne stavove (koji proizlaze iz praktičnih razloga poput onih vezanih za mogućnosti zaposlenja) (Baker i Prys Jones 1998: 174-178). ${ }^{9}$ S obzirom na to da u ovome radu istražujemo jezične stavove hrvatskih imigranata u Irskoj, ove se dvije skupine stavova u određenoj mjeri preklapaju. Engleski je većinski jezik u Irskoj, a većina ispitanika prije odlaska u Irsku učila ga je kao strani jezik. Dakako, samo istraživanje uključuje i stavove ispitanika prema svojemu materinskom jeziku, hrvatskome, koji je većinski jezik u državi iz koje su emigrirali.

Jezični stavovi nerijetko se istražuju u odnosu na samu jezičnu uporabu, ali i jezičnu politiku. Iako stavovi prema irskome jeziku nisu u središtu zanimanja ovoga rada, ovdje se možemo kratko osvrnuti i na njih, s obzirom na osobit odnos takvih stavova i jezične uporabe. Naime, koraci koji su početkom 21. stoljeća poduzeti u očuvanju irskoga jezika na makrorazini mogu se usporediti i sa stavovima prema irskome jeziku i uporabi irskoga jezika. Upravo o tome raspravlja Ó Laoire (2007: 166-167) te navodi da se unatoč pozitivnim stavovima prema irskome jeziku ipak ne zamjećuju znatniji pomaci u njegovoj uporabi, tj. dvojezičnost u najbitnijoj domeni - onoj obiteljskoj. Kao ilustraciju činjenice da dvije od tri komponente stavova - kognitivna i afektivna - katkada nisu usklađene, Baker (1992: 12-13) daje primjer situacije $\mathrm{u}$ kojoj osoba može istovremeno imati pozitivne stavove prema irskome jeziku $\mathrm{u}$

9 Baker (1992: 99-100) se referira na Katzovo (1960) razlikovanje četiriju funkcija stavova koje imaju ulogu u promjeni stavova, od kojih je jedna upravo instrumentalna. Druga funkcija je povezana $s$ obranom ega, gdje se osjećaj anksioznosti ili nesigurnosti dovodi u spregu s promjenom stavova, a kako bi se smanjila anksioznost ili osjećaj nesigurnosti (Baker 1992: 100). 
obrazovanju te negativne osjećaje (povezane s predrasudama, anksioznostima i strahovima) prema takvu obrazovanju. Treća komponenta stavova je spremnost na djelovanje, a Baker (1992: 13) upozorava na složenost odnosa stavova i samoga djelovanja.

Engleski jezik kao lingua franca proširio se svijetom, a s novim prostorima koje je osvajao, rastao je i broj domena u kojima se povećavala učestalost njegove uporabe u zemljama u kojima se smatra stranim jezikom. U istraživanju koje se bavi nenamjernim usvajanjem vokabulara engleskoga jezika, Mihaljević Djigunović i Geld (2002/2003: 337) raspravljaju o statusu engleskoga jezika u Hrvatskoj te navode da se on razlikuje od statusa ostalih jezika koji se u Hrvatskoj uče kao strani jezici, pri čemu se može promišljati o statusu engleskoga između drugog i stranog jezika. Na to se istraživanje, između ostalih, referiraju i Bogunović i Ćoso (2019: 6) kada zaključuju »da se u Hrvatskoj status engleskog kao stranog jezika mijenja te da je za mnoge postao drugi jezik«.

U hrvatskoj znanstvenoj literaturi brojna su istraživanja koja u obzir uzimaju jezične stavove i motivaciju za učenje engleskoga jezika. Mihaljević Djigunović i Geld (2002/2003: 337) navode viđenje engleskoga kao sredstva za ostvarivanje bolje karijere i društvenoga položaja te roditeljski pritisak da se osigura rano učenje engleskoga na nacionalnoj razini, a, s druge strane, navode i stavove onih kojima smeta količina engleskoga kojemu su, prije svega u medijima, Hrvati izloženi. Rezultati istraživanja Mihaljević Djigunović i Bagarić (2007: 277) o stavovima i motivaciji hrvatskih učenika engleskoga i njemačkoga pokazuju da učenici engleskoga jezika imaju pozitivnije stavove prema engleskome jeziku od učenika njemačkoga prema njemačkome jeziku, a razlike se tumače ponajprije neposrednim okružjem u kojem se jezik uči, razlikama u statusu jezika te izloženosti jezicima izvan nastavnoga konteksta. Ispitivanje stavova prema učenju engleskoga, njemačkoga i španjolskog jezika kao stranog jezika i jezika struke upućuje na razlike u stavovima i uvjerenjima prema učenju njemačkoga i španjolskoga ovisno o spolu i dobi, ali ne i prema učenju engleskoga jezika, što se tumači s važnosti jezika u struci, ali i izloženosti engleskome jeziku unutar i izvan školskog konteksta (Didović Baranac i dr. 2016). Komunikacijski i profesionalni razlozi važnosti poznavanja engleskoga jezika utvrđeni su i u istraživanju gledišta studenata koji uče engleski kao stručni strani jezik (Kuna 2007), a u ispitivanju razloga zbog kojih studenti Stomatološkog fakulteta Sveučilišta u Zagrebu biraju engleski kao nastavni kolegij, osim općeobrazovne, stručne, komunikativne, informativne i kulturološke orijentacije, navodi se i integrativna orijentacija vezana uz integraciju u jednu od zemalja engleskoga govornog područja (Štefić 1998). U istraživanju odnosa studenata prema engleskom jeziku struke koje su proveli Martinović i Poljaković (2010: 157) ističe se, između ostaloga, visoko vrednovanje engleskoga jezika za potrebe zaposlenja, obrazovanja i komunikacije na svjetskoj razini.

\section{Istraživanje jezične uporabe i stavova hrvatskih imigranata u Irskoj}

U ovome dijelu rada izlažu se metodologija i rezultati provedenoga istraživanja, koji su podijeljeni prema četiri dijela upitnika korištenog u istraživanju. Nakon opisa metodologije i prikaza rezultata slijedi rasprava o analiziranim podatcima. 


\subsection{Metodologija}

Istraživanje čija je svrha ispitati emigracijska i jezično povezana iskustva i stavove Hrvata u Irskoj provedeno je od lipnja do kolovoza 2019. godine upitnikom koji su hrvatski iseljenici u Irskoj ispunili putem društvene mreže Facebook. ${ }^{10} \mathrm{Za}$ izradu upitnika koristio se Googleov obrazac za strukturiranje upitnika, a ispitanicima je objašnjena svrha istraživanja te im je osigurana potpuna anonimnost. U prvome dijelu upitnika od ispitanika se tražilo da navedu opće podatke o sebi te podatke o mjestu iz kojeg i u koje su migrirali, okolnostima u kojima su migrirali i trajanju boravka u Irskoj. U drugom dijelu upitnika ispitanicima su ponuđena pitanja vezana za stavove o Irskoj i Hrvatskoj, kao i uvodna pitanja o engleskom i hrvatskom jeziku. U trećem dijelu ispitanici su odgovarali na pitanja vezana za njihovo učenje, uporabu i poznavanje engleskog jezika te za pojedine aspekte socijalizacije u odnosu na jezik. Četvrti dio upitnika ispunjavali su samo ispitanici koji imaju djecu te se od njih tražilo da iskažu stavove prema uporabi hrvatskoga i engleskoga jezika svoje djece.

\subsection{Ispitanici}

U istraživanju su sudjelovala 82 ispitanika, ${ }^{11}$ od kojih 51 osoba ženskoga spola (62,2 \% ispitanika) i 31 osoba muškoga spola (37,8 \% ispitanika). Većina ispitanika $(81,7 \%)$ pripada ranoj odrasloj dobi, a manji dio $(18,3 \%)$ srednjoj odrasloj dobi. Nitko od ispitanika ne pripada kasnoj odrasloj dobi. ${ }^{12}$ Od 82 ispitanika, njih 2,4\% završilo je osnovnu školu, 47,6 \% završilo je srednju školu, 20,7 \% preddiplomski studij, 26,8 \% diplomski studij, a 2,4 \% doktorski studij.

U odgovorima većine ispitanika $(71,9 \%)$ vidljivo je preklapanje grada ili mjesta podrijetla te grada ili mjesta koji su napustili dolaskom u Irsku. Najviše ispitanika ima podrijetlo u gradovima ili mjestima koja se nalaze u sljedećim hrvatskim županijama: Grad Zagreb (25,6 \%), Primorsko-goranska županija (10,9 \%), Osječkobaranjska (9,8 \%) i Sisačko-moslavačka županija (6,09\%). Nadalje, odlaskom u Irsku najviše ih je napustilo gradove ili mjesta koja se nalaze u sljedećim županijama: Grad Zagreb (30,4 \%), Primorsko-goranska županija (13,9 \%), Osječko-baranjska županija (7,6 \%), Varaždinska županija (5,06 \%), Vukovarsko-srijemska županija $(5,06 \%)$ i Zadarska županija $(5,06 \%)$.

Za većinu ispitanika (86,6 \%) Irska je prva zemlja u koju su emigrirali. Jedanaest osoba $(13,4 \%)$ odgovorilo je da Irska nije prva zemlja u koju su emigrirali. Prije odlaska u Irsku emigrirali su, primjerice, u Njemačku, Češku, Švedsku i Škotsku. Duljina njihova boravka u drugim zemljama je od šest mjeseci do dvije godine. Kada je riječ o emigraciji u Irsku, najviše je ispitanika emigriralo u sljedeće irske gradove: Dublin (42,7 \%), Cork (9,8 \%) i Galway (8,5 \%). Duljina njihova boravka u Irskoj je od dva mjeseca do četiri godine, a dominantno ${ }^{13}$ iskazano trajanje boravka u Irskoj

10 Upitnik se nalazi u prilogu ovoga rada.

11 Pojedini ispitanici nisu ponudili odgovore na sva pitanja u upitniku, što se uzima u obzir u analizi rezultata.

12 Razvojna periodizacija prema Berk (2008: 8) uključuje, između ostalog, ranu odraslu dob (od 20 do 40 godina), srednju odraslu dob (od 40 do 60 godina) i kasnu odraslu dob (od 60 godina do kraja života).

13 Dominantna vrijednost (mod) kao mjera središnje tendencije. 
$(19,5 \%)$ iznosi tri godine. 51,2 \% ispitanika u Irsku je došlo s obitelji, dok je njih $48,8 \%$ u Irsku došlo samo.

\subsection{Stavovi o Irskoj i Hrvatskoj te uvodna pitanja o engleskom i hrvatskom jeziku}

Većina ispitanika slaže se ili u potpunosti slaže $(79,2 \%)^{14}$ s tvrdnjom da su Irci gostoljubiv narod te se slaže ili u potpunosti slaže $(78,1 \%)$ da se u Irskoj dobro osjeća. Većina njih u potpunosti se slaže ili slaže $(92,7 \%)$ da želi dobro naučiti engleski jezik te se uopće ne slaže ili ne slaže (84,2 \%) da je engleski jezik težak. Na upit nedostaje li im Hrvatska, relativno visok broj ispitanika niti se slaže, niti ne slaže (22 \%). Međutim, ipak je veći udio onih koji se ne slažu ili uopće ne slažu (42,7 \%) od onih koji se slažu ili u potpunosti slažu $(35,3 \%)$ da im nedostaje Hrvatska. Iako se ispitanici dominantno niti slažu, niti ne slažu da im nedostaje komunikacija na hrvatskom jeziku (30,5 \%), ipak je veći udio onih koji se s tvrdnjom uopće ne slažu ili ne slažu $(48,8 \%)$ od onih koji se s njom slažu ili u potpunosti slažu (20,8 \%). Iako se 20,7 \% ispitanika niti slaže, niti ne slaže, većina se u potpunosti slaže ili slaže $(58,5 \%)$ da planira ostati u Irskoj, dok se njih 20,7 \% uopće ne slaže ili ne slaže s navedenom tvrdnjom. Iako je i kod tvrdnje vezane za planirani povratak u Hrvatsku relativno visok udio onih koji se niti slažu, niti ne slažu (28 \%), ipak je veći udio onih koji se s time uopće ne slažu ili ne slažu (52,4 \%) od onih koji se s tvrdnjom u potpunosti slažu ili slažu (19,5 \%). Distribucija odgovora na tvrdnje u ovom dijelu istraživanja prikazana je na slici 1.

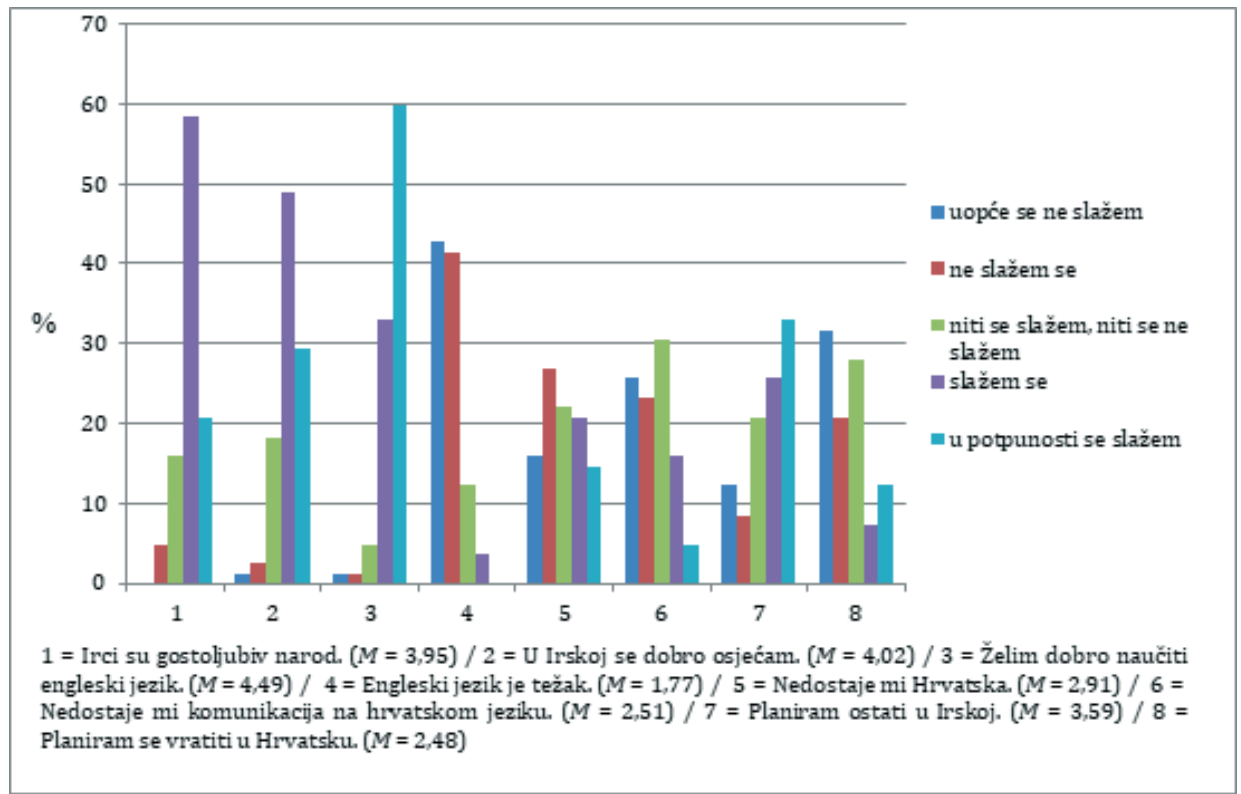

Slika 1. Distribucija odgovora ispitanika na tvrdnje o Irskoj i Hrvatskoj te engleskom i hrvatskom jeziku

14 Navedeni postotak predstavlja zbroj postotaka onih koji se slažu i postotak onih koji se u potpunosti slažu s tvrdnjom. Na slici prikazanoj u nastavku vidljivo je koja je od dvije vrijednosti dominantna. Na slici su za svaku tvrdnju navedene i aritmetičke sredine (M (eng. mean)) odgovora ispitanika. 


\subsection{Učenje, uporaba i poznavanje engleskog jezika}

U ovome dijelu izlažu se rezultati vezani za učenje engleskog jezika, njegovu uporabu u Hrvatskoj te znanje engleskoga jezika prije i nakon dolaska u Irsku. Tome slijede rezultati vezani za uporabu engleskog jezika na radnom mjestu i u društvenom životu ispitanika u Irskoj.

\subsubsection{Učenje engleskog, njegova uporaba u Hrvatskoj te znanje prije i nakon dolaska} u Irsku

Većina ispitanika $(64,7 \%)$ učila je engleski jezik u različitim trajanjima kraćim od 12 godina, njih $23,1 \% 12$ godina ${ }^{15}$ te njih $12,2 \%$ u različitim trajanjima duljim od 12 godina. Većina ispitanika (52,4 \%) učila je engleski u osnovnoj i srednjoj školi. Njih 36,6 \% engleski je učilo u osnovnoj, srednjoj školi i na fakultetu, dok je jedna osoba (1,2 \% ispitanika) učila engleski samo u osnovnoj školi. Manji udio ispitanika, njih 9,8 \%, nikad nije učio engleski. Većina ispitanika (79,3\%) odgovorila je da se prije dolaska u Irsku koristila engleskim, dok je njih 20,7 \% odgovorilo da se prije dolaska u Irsku nije koristilo engleskim. Oni koji su se koristili engleskim u Hrvatskoj u različitim omjerima, ovisno o kontekstu uporabe, složili su se ili u potpunosti složili da su se služili engleskim. Riječ je o sljedećim udjelima, počevši od najčešćega konteksta uporabe: na društvenim mrežama (86,3 \%), u razgovoru sa strancima (84,9 \%), u obrazovnim ustanovama (u školi ili na fakultetu) (61,1\%), na radnom mjestu (45,8 \%), u razgovoru s prijateljima (12,3 \%) te u razgovoru s obitelji $(2,9 \%)$. Distribucija odgovora na ove tvrdnje prikazana je na slici 2.

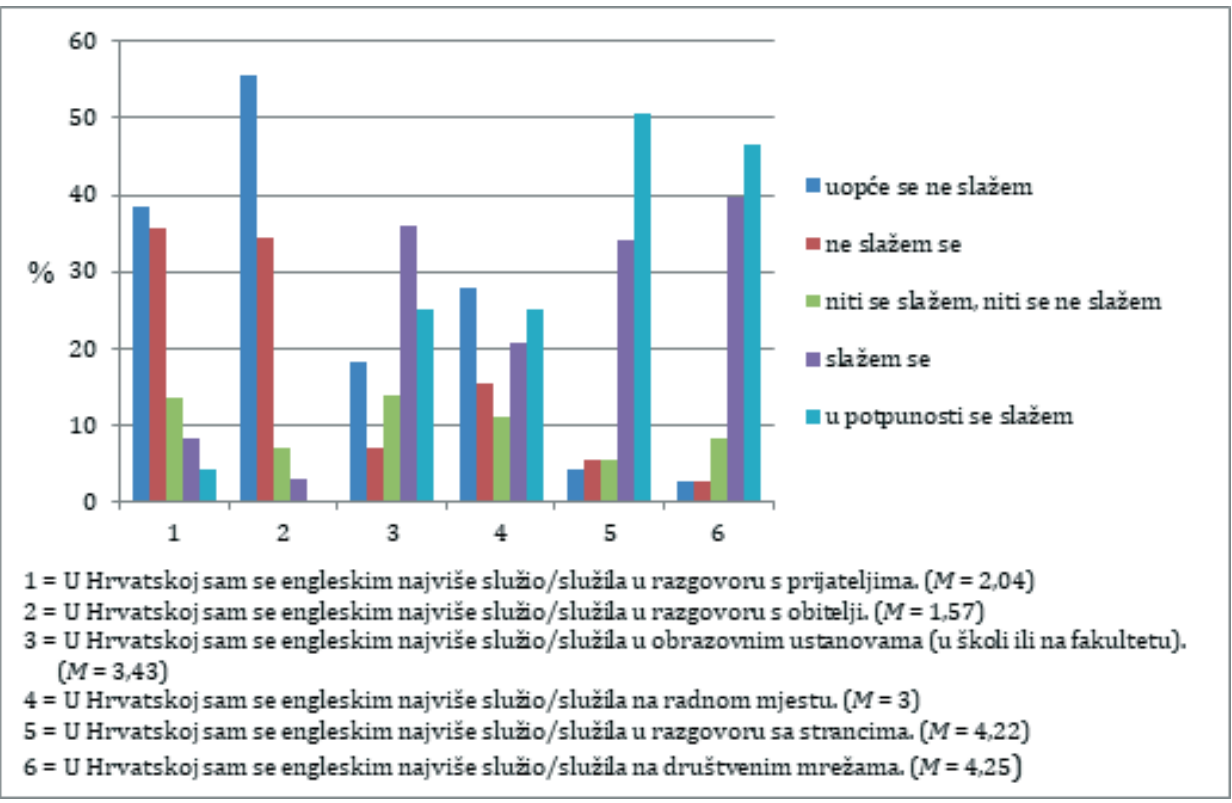

Slika 2. Distribucija odgovora ispitanika na tvrdnje o uporabi engleskoga jezika u Hrvatskoj

15 Dominantno iskazano trajanje. 
Tek je 8,5 \% ispitanika procijenilo svoje znanje engleskog jezika prije dolaska u Irsku mnogo lošijim ili lošijim od prosjeka, dok ga je njih 58,6 \% procijenilo boljim ili mnogo boljim od prosjeka. S druge strane, nitko od ispitanika nije svoje trenutačno znanje engleskoga procijenio mnogo lošijim ili lošijim od prosjeka. Njih 87,8 \% smatra da je njihovo trenutačno znanje engleskoga jezika bolje ili mnogo bolje od prosjeka. Distribucija odgovora na ove tvrdnje prikazana je na slici 3.

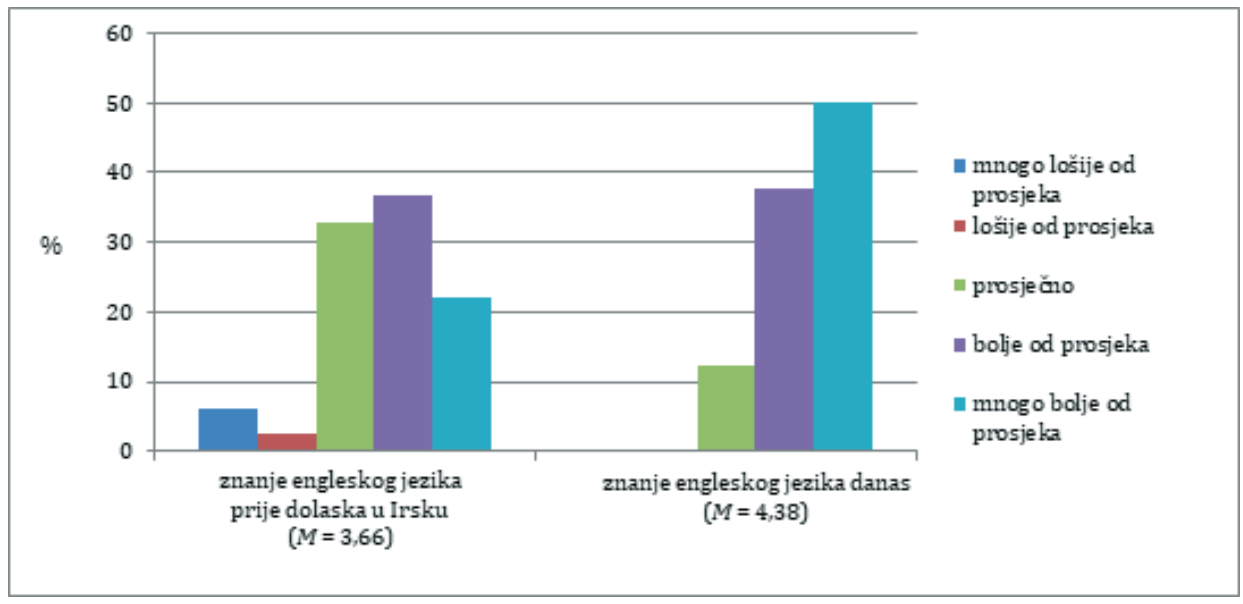

Slika 3. Distribucija odgovora ispitanika na tvrdnje o njihovu znanju engleskog jezika

Većina (86,6 \%) ih je kazala da im prilikom dolaska u Irsku nije bila pružena pomoć s engleskim, dok je njih $11(13,4 \%)$ pomoć dobilo. Među njima je dvoje odgovorilo da im je pomoć bila sama pružena, a devetero da su pomoć potražili sami. Primjeri pomoći koja im je bila pružena osobna su pomoć Iraca, tečajevi ili pomoć prijatelja Hrvata.

\subsubsection{Uporaba engleskog jezika na radnom mjestu i u društvenom životu u Irskoj}

Većina ispitanika $(86,1 \%)$ odgovorila je da se vrlo često koristi engleskim jezikom na radnom mjestu. Značajan udio njih radi u uslužnim djelatnostima (31,7 \%). Od ostalih navedenih radnih mjesta može se izdvojiti da 12,1 \% ispitanika radi u zdravstvu, a njih 7,3 \% u IT industriji. ${ }^{16}$

Relativno visok udio ispitanika (30,9 \%) niti se slaže, niti ne slaže s tvrdnjom da je u Irskoj moguće naći posao bez ikakvog znanja engleskog jezika. Ipak, znatno je veći udio onih koji se s time u potpunosti slažu ili slažu (49,4\%) od onih koji se uopće ne slažu ili ne slažu (19,8 \%). Iako se $21,8 \%$ ispitanika niti slaže, niti ne slaže s time da je poslodavcu prilikom njihova zapošljavanja bilo bitno znanje engleskog jezika, ipak je znatno veći broj ispitanika koji se slažu ili u potpunosti slažu $(61,6 \%)$ u odnosu na one koji se ne slažu ili uopće ne slažu $(16,6 \%)$ s ispitivanom tvrdnjom.

Nadalje, čak se $84,9 \%$ ispitanika u potpunosti slaže ili slaže da je na radnom mjestu obvezno govoriti engleski jezik te njih 87,2 \% da je na radnome mjestu unaprijedilo svoje znanje engleskoga jezika. Distribucija odgovora na ove tvrdnje prikazana je na slici 4.

16 Odgovori ostalih ispitanika bili su raznovrsni zbog čega ih nije bilo moguće grupirati na sličan način. 


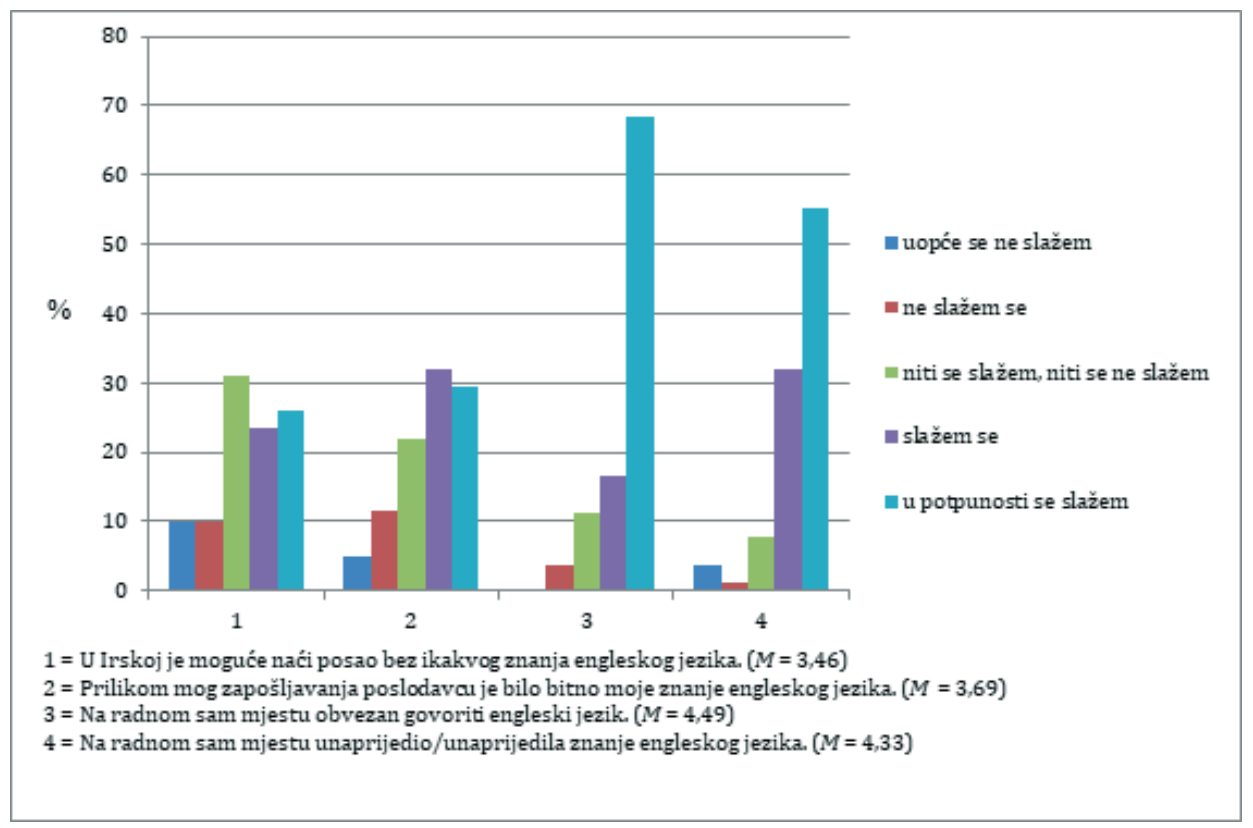

Slika 4. Distribucija odgovora ispitanika na tvrdnje

o uporabi engleskog jezika na radnom mjestu

Od 82 ispitanika, njih 43,2 \% odgovorilo je da se najviše druži s Hrvatima. Među ostalima, 34,6 \% najviše se druži s pripadnicima ostalih nacionalnosti, dok se njih 22,2 \% najviše druži s Ircima. Najveći broj ispitanika koji se druže s pripadnicima ostalih nacionalnosti $(57,6$ \%) naveo je da se najviše druži s Poljacima.

Većina ispitanika (94,3 \%) odgovorila je da se uopće ne slaže ili ne slaže s tvrdnjom Najviše se družim s Hrvatima jer ne znam engleski jezik. Također, većina se uopće ne slaže ili ne slaže s tvrdnjom Najviše se družim s Hrvatima jer se sramim svog znanja engleskog jezika (96,1 \%). I kod tvrdnji Jedino me Hrvati u potpunosti razumiju pa se zato s njima i najviše družim (86,6 \%), Najviše se družim s Hrvatima jer mi njihov mentalitet najviše odgovara (71,2 \%) i Najviše se družim s Hrvatima jer tako umanjujem svoju nostalgiju za domom i materinskim jezikom (61,6 \%) značajan je broj onih koji se s njima uopće ne slažu ili ne slažu. Međutim, uspoređujući odgovore na prve dvije tvrdnje s odgovorima na sljedeće tri, zamjećuje se porast broja ispitanika koji se s njima slažu ili u potpunosti slažu. Distribucija odgovora svih ispitanika na navedene tvrdnje nalazi se na slici 5. 


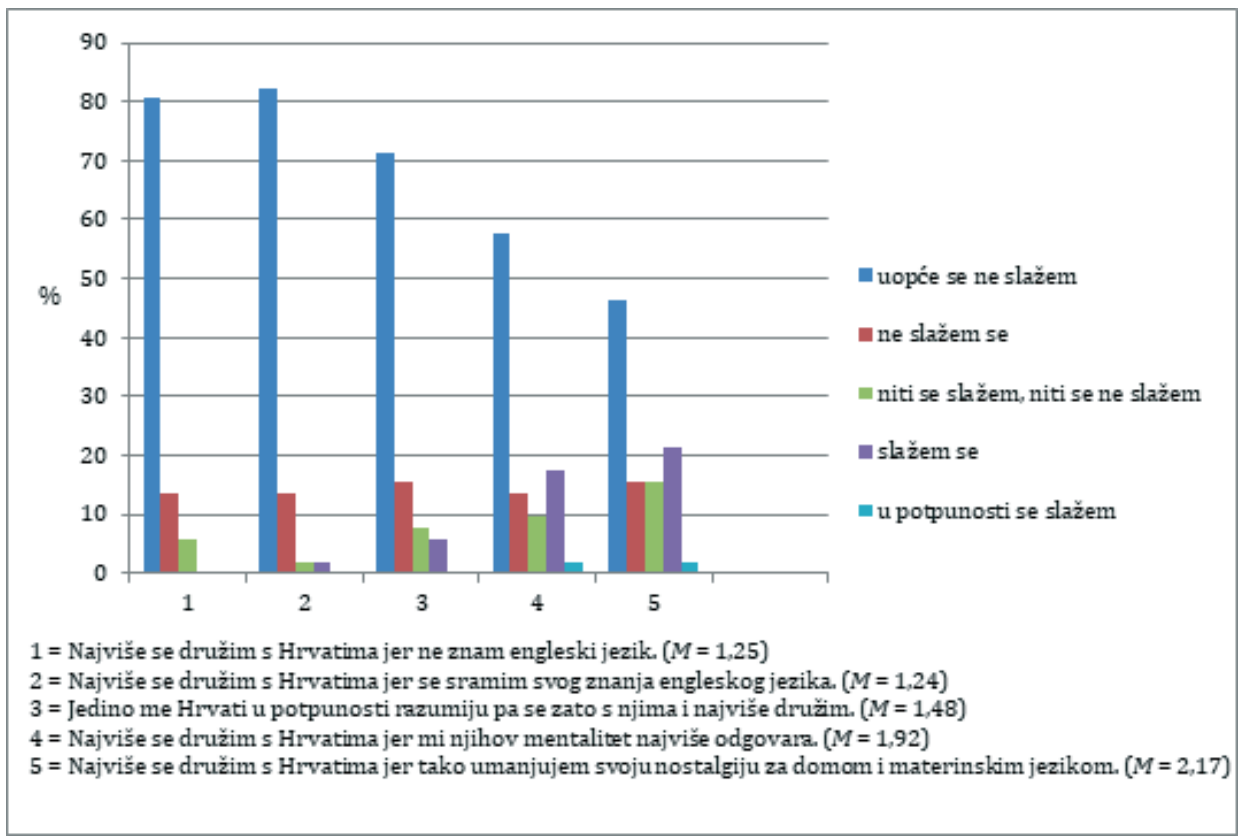

Slika 5. Distribucija odgovora ispitanika na tvrdnje o uporabi engleskog jezika u društvenom životu

\subsection{Jezična uporaba i stavovi - djeca ispitanika}

Dvadeset dvoje ispitanika ima djecu. Većina (52,6 \%) ima jedno dijete, a raspon dobi djece ispitanika je od tri mjeseca do šesnaest godina. Prema većini ispitanih (68,2 \%) njihova se djeca najviše druže s Ircima, zatim s Hrvatima (22,7 \%) te s pripadnicima drugih nacionalnosti $(9,1 \%)$. Većina njih (50 \%) navela je Poljake kao pripadnike drugih nacionalnosti s kojim se njihova djeca najviše druže.

Unatoč visoku udjelu ispitanika (34,8 \%) koji se niti slažu, niti ne slažu da njihova djeca moraju znati hrvatski jezik, znatno je veći udio ispitanika $(56,5 \%)$ koji se s time u potpunosti slažu ili slažu od onih koji se uopće ne slažu ili ne slažu $(8,6 \%)$. Dok se 71,4 \% ispitanika ne slaže ili uopće ne slaže s tvrdnjom Moja se djeca najviše druže s Hrvatima jer tako rade na očuvanju hrvatskog jezika, nitko od njih nije naveo da se s time slaže ili u potpunosti slaže. Čak se 42,9 \% ispitanika niti slaže, niti ne slaže s tvrdnjom Moja se djeca najviše druže s Hrvatima jer je bitno u stranome svijetu održavati veze s ljudima iz svoje zemlje, a njih 57,1 \% uopće se ne slaže ili ne slaže. Ispitanici se dominantno (47,6 \%) niti slažu, niti ne slažu s tvrdnjom Moja djeca žele govoriti hrvatski jezik, iako je veći broj onih koji se s time slažu ili u potpunosti slažu (38 \%) od onih koji se ne slažu ili uopće ne slažu (14,3 \%). Većina ispitanika (52,4 \%) uopće se ne slaže ili ne slaže da je njihovoj djeci hrvatski jezik teži od engleskoga, a 33,3 \% njih se niti slaže, niti ne slaže. Ispitanici se dominantno $(47,6 \%)$ niti slažu, niti ne slažu da njihova djeca više vole engleski nego hrvatski, dok se njih 33,3 \% ne slaže ili uopće ne slaže s navedenim. Ispitanici se također dominantno $(38,1 \%)$ niti 
slažu, niti ne slažu s tvrdnjom Potičem svoju djecu da se druže s Ircima jer će tako brže i bolje naučiti engleski jezik, dok se njih 38 \% slaže ili u potpunosti slaže s navedenim. Većina ispitanika (55 \%) uopće se ne slaže ili ne slaže da im njihova djeca pomažu s engleskim, dok se njih 30 \% niti slaže, niti ne slaže. Distribucija odgovora svih ispitanika na navedene tvrdnje prikazana je na slici 6.

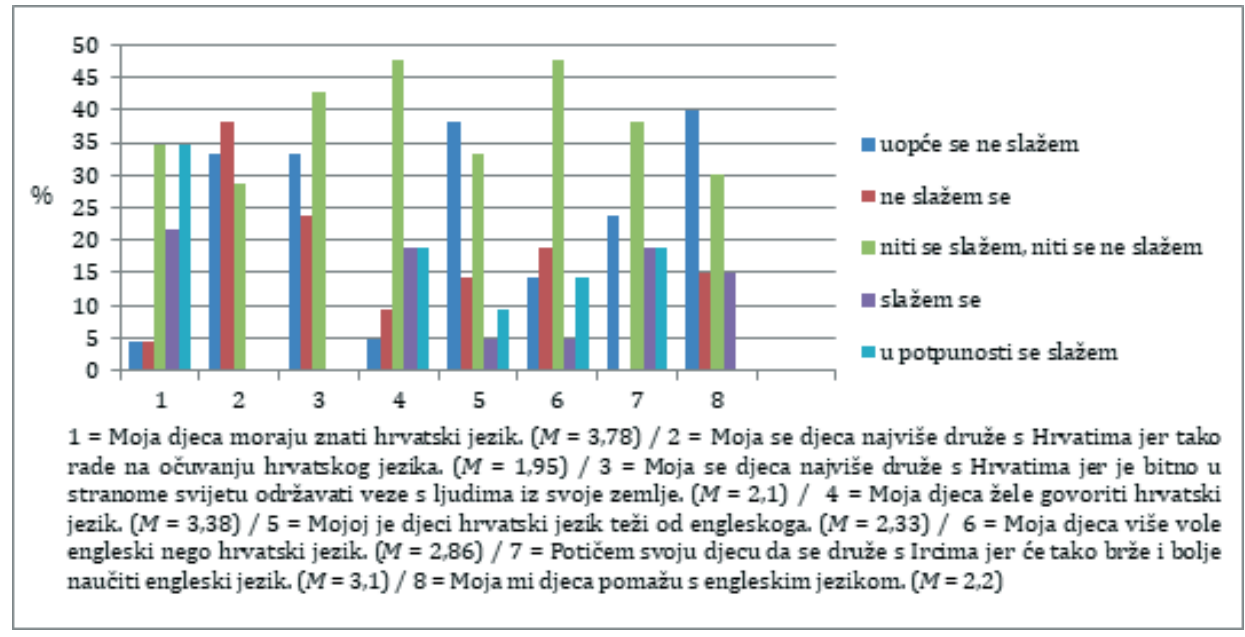

Slika 6. Distribucija odgovora ispitanika s djecom na tvrdnje o jezičnim stavovima i jezičnoj uporabi njihove djece

\subsection{Rasprava}

U drugome dijelu upitnika ispitanici su izražavali opće stavove o Irskoj i Hrvatskoj te odgovarali na uvodna pitanja o jeziku. Rezultati ovoga dijela istraživanja pokazuju da ispitanici imaju pozitivne stavove prema boravku u Irskoj, što je potvrđeno dominantno iskazanom percepcijom Iraca kao gostoljubivog naroda te činjenicom da se većina ispitanika u Irskoj dobro osjeća. Ispitanici nisu iskazali izrazito nedostajanje rodne zemlje, kao ni planiranje povratka u Hrvatsku. Među ispitanicima postoji izrazita želja za dobrim ovladavanjem engleskim jezikom, koji većina ispitanika ne smatra teškim za učenje. Većina također nije iskazala izrazito nedostajanje komunikacije na hrvatskome jeziku.

Treći je dio upitnika uključivao pitanja o učenju, uporabi i znanju engleskoga jezika. Većina ispitanika učila je engleski jezik manje od 12 godina, i to u osnovnoj i srednjoj školi. Samo manji udio ispitanika nije se koristio engleskim prije dolaska u Irsku. Oni koji su se koristili njime, činili su to u najvećoj mjeri na društvenim mrežama te u razgovoru sa strancima, u nešto manjoj mjeri u obrazovnim ustanovama te na radnome mjestu, a u najmanjoj mjeri u razgovoru s prijateljima i obitelji. Procjena vlastitoga znanja engleskoga jezika među ispitanicima pokazuje da se njihovo znanje nakon dolaska u Irsku poboljšalo, iako većina njih ni svoje znanje engleskoga prije dolaska u Irsku nije ocijenila lošim. Nadalje, većina nije imala pomoć s engleskim prilikom dolaska u Irsku, dok je manjem broju njih pomoć ili sama pružena ili su je tražili, i to od Iraca, putem tečajeva ili od drugih Hrvata. Engleskim jezikom na 
radnome mjestu u Irskoj koristi se vrlo često, a velik dio ispitanika radi u uslužnim djelatnostima i nešto manji broj u zdravstvu i IT industriji te na raznim drugim mjestima. Velik broj ispitanika smatra da je u Irskoj moguće pronaći posao bez znanja engleskoga jezika. S druge strane, velik je i broj ispitanika koji tvrde da je poslodavcu bilo bitno njihovo poznavanje engleskoga jezika. Velika je većina ispitanika na radnome mjestu obvezna govoriti engleski jezik, na kojem su i unaprijedili svoje znanje engleskoga jezika. Gotovo nitko od ispitanika nije povezao druženje s Hrvatima s neznanjem engleskoga ili neugodom zbog vlastite razine znanja engleskoga jezika. Većina ne povezuje druženje s Hrvatima ni s međusobnim razumijevanjem, sličnim mentalitetom, kao ni umanjivanjem nostalgije za domom i materinskim jezikom, iako se kod ove tri poveznice zamjećuje blagi porast u broju onih koji utvrđuju takvu vezu.

Četvrti dio upitnika ispunjavali su ispitanici koji imaju djecu. Znatan je dio ispitanika bio neodlučan u odgovorima na tvrdnje u ovome dijelu upitnika, što se može povezati s dobi njihove djece, koja je od tri mjeseca do šesnaest godina. Unatoč tome, značajan je broj ispitanika koji smatraju da njihova djeca moraju znati hrvatski jezik. Druženje djece s Hrvatima uglavnom se ne dovodi u vezu s očuvanjem hrvatskoga jezika ni s održavanjem veze s ljudima iz rodne zemlje. Iako je velik broj ispitanika neodlučan oko toga žele li njihova djeca govoriti hrvatski jezik, više je onih koji se slažu s time od onih koji se ne slažu. Velik broj ispitanika neodlučan je i oko toga je li djeci hrvatski teži od engleskog jezika te vole li djeca više engleski nego hrvatski, ali se više ne slažu nego slažu. Značajan dio ispitanika je neodlučan i oko toga potiču li djecu da se druže s Ircima jer će tako brže i bolje naučiti engleski jezik, iako se više njih slaže nego ne slaže. Ispitanici su neodlučni i oko toga pomažu li im djeca s engleskim, iako se više njih ne slaže nego slaže.

\section{Zaključak}

Značajke državnih jezičnih politika nerijetko ovise o različitim povijesnim, političkim i/ili ekonomskim čimbenicima. Utjecaj navedenih čimbenika vidljiv je, primjerice, u analizama jezičnih politika država čije su povijesti obilježene raznim previranjima i političkim tenzijama s drugim političkim entitetima. Složenost analize jezičnih politika postaje izraženija ako je riječ o tradicionalno imigracijskim državama, poput SAD-a ili Kanade, ali i ako su predmet analize jezične politike država koje su tek u posljednje vrijeme izraženije postale poželjna destinacija određenih skupina imigranata.

$\mathrm{Na}$ irski identitet povijesno je značajno utjecao odnos s Engleskom, a u novije vrijeme ekonomski razvoj te uključivanje u Europsku uniju. Izraženiji interes pojedinih skupina imigranata za odlazak u Irsku potaknuo je nastojanja da se osmisli odgovarajuća strategija integracije imigranata. Strategija integracije imigranata (2017) bitan je dokument za analizu ne samo irske imigracijske politike nego i one jezične. Dokument otkriva važnost jezične komponente, odnosno iznalaženja načina na koje bi se imigrantima trebale pružiti informacije, ali i pomoć pri ovladavanju jezikom. Pritom je naglašena i sprega poznavanja engleskoga jezika i integracije na radnome mjestu. S druge strane, poznavanje engleskoga jezika trenutačno nije postavljeno kao preduvjet za stjecanje državljanstva, iako Strategija predviđa 
razmatranje uvođenja provjere poznavanja engleskoga jezika. Razvidno je stoga da se, s porastom imigranata u Irskoj te promjenama u irskoj imigracijskoj politici, javljaju naznake promjena i u njezinoj jezičnoj politici.

Znatna je pozornost posvećena opisu emigracije Hrvata u dominantno anglofone i tradicionalno imigracijske zemlje, a u posljednje vrijeme i opisu njihove emigracije u europske zemlje. Tome je svakako doprinijelo članstvo Hrvatske u Europskoj uniji. Irska je zbog niza čimbenika privlačna destinacija hrvatskim emigrantima, među kojima se ističe i poznavanje engleskoga jezika (Rajković Iveta i Horvatin 2017). Razlozi isticanja poznavanja engleskoga jezika kao relevantnog čimbenika za odabir Irske kao destinacije mogu se povezati ne samo s izloženosti jeziku formalnim obrazovanjem nego i izloženosti izvan obrazovnog konteksta. Takva izloženost svakako utječe na stvaranje pozitivnih stavova prema engleskome jeziku (Mihaljević Djigunović i Bagarić 2007), što opet doprinosi njegovoj češćoj uporabi.

Istraživanje provedeno od lipnja do kolovoza 2019. godine među hrvatskim iseljenicima u Irskoj imalo je za svrhu istražiti emigracijska i jezično povezana iskustva i stavove Hrvata u Irskoj. Pozitivni stavovi prema životu u Irskoj mogu se u određenoj mjeri povezati sa stavovima prema engleskome jeziku i jezičnom uporabom. Takvi se rezultati vezani za pozitivne stavove prema engleskome jeziku mogu dovesti u vezu i s nizom prethodno provedenih istraživanja (od kojih su neka spomenuta u ovome radu) u neemigracijskim kontekstima, a koja također svjedoče o pozitivnim stavovima Hrvata prema engleskome jeziku. U migracijskom kontekstu razvidno je da se takvi stavovi odnose ponajprije na pragmatičnu funkciju, odnosno vrijednost engleskoga jezika. Stoga možemo govoriti o onome što Baker i Prys Jones (1998: 174-178) nazivaju instrumentalnim stavovima, odnosno o instrumentalnim razlozima zbog kojih su među hrvatskim imigrantima u Irskoj stavovi prema engleskome jeziku pozitivni. Time se može objasniti i činjenica da njima komunikacija na hrvatskome jeziku ne nedostaje u većoj mjeri.

Iako su stavoviprema anglizmima u hrvatskome jeziku te oniprema učenju engleskoga jezika u hrvatskom kontekstu relativno dobro opisani, sa sociolingvističkoga stajališta u novije vrijeme osobito su zanimljiva istraživanja uporabe engleskoga jezika i stavova prema engleskome jeziku u imigrantskim kontekstima. U takvim je kontekstima pragmatična vrijednost jezika države domaćina najjasnija i u svezi je prije svega s ekonomskim čimbenicima. Emigracija Hrvata u Irsku je relativno nov fenomen, zbog čega je upitna mjera u kojoj se može smatrati trajnom. To je ujedno i razlog zašto su opisi stupnja i načina očuvanja hrvatskoga jezika među pripadnicima više generacija imigranata u ovome trenutku relativno ograničena. Ako se emigracija Hrvata u Irsku pokaže trajnom, buduća bi sociolingvistička istraživanja mogla pružiti odgovor i na to pitanje.

\section{Literatura}

Baker, C. 1992. Attitudes and language. Clevedon: Multilingual Matters.

Baker, C.; Prys Jones, S. 1998. Encyclopedia of bilingualism and bilingual education. Clevedon: Multilingual Matters.

Berk, L. E. 2008. Psihologija cjeloživotnog razvoja. (ur. hrv. izd. Gordana Keresteš). Jastrebarsko: Naklada Slap. 
Bogunović, I.; Ćoso, B. 2019. „Leksički pristup hrvatskih govornika engleskog s različitim razinama jezičnog znanja." Suvremena lingvistika, 45(87), 1-22.

Böss, M. 2010. "Irish neutrality: From nationalism to postnationalism." U Irene Gilsenan Nordin, Carmen Zamorano Llena (ur.), Redefinitions of Irish identity: A postnationalist approach (str. 17-36). Bern: Peter Lang.

Crowley, T. 2000. The politics of language in Ireland 1366-1922: A sourcebook. London \& New York: Routledge.

Didović Baranac, S; Falkoni-Mjehović; D.; Vidak, N. 2016. „Ispitivanje stavova prema učenju engleskoga, njemačkoga i španjolskog jezika kao stranog jezika i jezika struke." Zbornik Sveučilišta u Dubrovniku, 3, 11-30.

Garner, S. 2004. Racism in the Irish experience. London: Pluto Press.

Hayward, K. 2009. Irish nationalism and European integration: The official redefinition of the island of Ireland. Manchaster: Manchaster University Press.

Kamusella, T. 2018. "Nationalism and national languages." U James W. Tollefson, Miguel Pérez-Milans (ur.), The Oxford Handbook of Language Policy and Planning (str. 163-182). New York: Oxford University Press.

Kuna, D. 2007. „Gledišta studenata Filozofskoga fakulteta u Osijeku o nastavi engleskoga kao stranoga jezika." Život i škola: časopis za teoriju i praksu odgoja i obrazovanja, 53(1), 28-36.

Lajić, I. 2004. „Noviji razvoj stanovništva Hrvatske - regularno i neregularno kretanje stanovništva." Migracijske i etničke teme, 20(2-3), 171-185.

Lentin, R.; Moreo, E. (ur.) 2012. Migrant activism and integration from below in Ireland. Basingstoke: Palgrave Macmillan.

Mac Giolla Chríost, D. 2008. "Micro-level language planning in Ireland." U Anthony J. Liddicoat, Richard B. Jr. Baldauf (ur.), Language planning and policy: Language planning in local contexts (str. 75-94). Clevedon: Multilingual Matters.

Martinović A; Poljaković, I. 2010. "Attitudes towards ESP among university students." Fluminensia, 22(2), 145-161.

Maurais, J; Morris, M. A. 2003. "Introduction." U Jacques Maurais, Michael A. Morris (ur.), Languages in a globalising world (str. 1-10). Cambridge: Cambridge University Press. Izvorno objavljeno na francuskome jeziku: "Géostratégies des langues." U Terminogramme. Les Publications de Québec i Office de la langue française (2001).

Mihaljević Djigunović, J.; Bagarić, V. 2007. "A comparative study of attitudes and motivation of Croatian learners of English and German." Studia Romanica et Anglica Zagrabiensia, 52, 259-281.

Mihaljević Djigunović, J.; Geld, R. 2002./2003. "English in Croatia today: Opportunities for incidental vocabulary acquisition." Studia Romanica et Anglica Zagrabiensia, 47-48, 335-352.

Moriarty, M. 2015. Globalizing language policy and planning: An Irish language perspective. Basingstoke: Palgrave Macmillan.

Ó Laoire, M. 2007. "Language use and language attitudes in Ireland." U David Lasagabaster, Ángel Huguet (ur.), Multilingualism in European bilingual contexts: Language use and attitudes (str. 164-183). Clevedon: Multilingual Matters. 
Rajković Iveta, M.; Horvatin, T. 2017. „Suvremeno iseljavanje iz Hrvatske u Irsku s posebnim osvrtom na mlade iz Slavonije." Migracijske i etničke teme, 33(3), 247-274.

Ricento, T. 2018. "Globalization, language policy, and the role of English." U James W. Tollefson, Miguel Pérez-Milans (ur.), The Oxford handbook of language policy and planning (str. 221-235). New York: Oxford University Press.

Sebba, M. 2011. "Societal bilingualism." U Ruth Wodak, Barbara Johnstone, Paul Kerswill (ur.), The SAGE handbook of sociolinguistics (str. 445-459). London: SAGE.

Škifić, S. 2013. "Citizenship as an instrument of inclusion and exclusion - A comparative analysis of language requirements in naturalization processes in the United States, Canada, Australia, and New Zealand." Lengua y migración (Language and Migration), 5(1), 5-32.

Štefić, L. 1998. „Razlozi zbog kojih studenti Stomatološkog fakulteta Sveučilišta u Zagrebu odabiru engleski jezik kao nastavni kolegij.“ Acta Stomatologica Croatica, 32(2), 305-322.

Zlatković Winter, J. 2001. „Državljanstvo, nacionalni identitet i migracije: europska perspektiva." Revija za sociologiju, 32(1-2), 39-47.

\section{Mrežni izvori}

Irish Naturalisation and Immigration Service (INIS). http://www.inis.gov.ie/. (20. 7. 2019.).

Ross-Lonergan, K. 2009. "Immigration and social change in contemporary society: An assessment of the process of integration and the 'recognition' of ethnic minorities." Critical Social Thinking: Policy and Practice, 1, 333-344. https:// www.ucc.ie/en/appsoc/resconf/conf/cst/vol1/. (19.7. 2019.).

The Migrant Integration Strategy. 2017. Department of Justice and Equality. Office for the Promotion of Migrant Integration. http://www.integration.ie/en/ isec/pages/migrant_integration_strategy. (20. 7. 2019.).

Zakon o hrvatskom državljanstvu 1991. Hrvatski sabor. Narodne novine broj 53/1991. https://narodne-novine.nn.hr/clanci/sluzbeni/1991_10_53_1272. html (29. 8. 2019.). 
Prilozi

Popis slika

Slika 1. Distribucija odgovora ispitanika na tvrdnje o Irskoj i Hrvatskoj te engleskom i hrvatskom jeziku

Slika 2. Distribucija odgovora ispitanika na tvrdnje o uporabi engleskoga jezika u Hrvatskoj

Slika 3. Distribucija odgovora ispitanika na tvrdnje o njihovu znanju engleskog jezika

Slika 4. Distribucija odgovora ispitanika na tvrdnje o uporabi engleskog jezika na radnom mjestu

Slika 5. Distribucija odgovora ispitanika na tvrdnje o uporabi engleskog jezika u društvenom životu

Slika 6. Distribucija odgovora ispitanika s djecom na tvrdnje o jezičnim stavovima i jezičnoj uporabi njihove djece 


\section{Upitnik}

Poštovani/a, pred Vama je anonimni upitnik čija je svrha istražiti emigracijska i jezično povezana iskustva i stavove Hrvata u Irskoj. Molimo Vas da na pitanja odgovorite iskreno. Zahvaljujemo Vam na strpljenju i suradnji.

1. Dob:

2. Spol: $\mathrm{M} / \check{\mathrm{Z}}$

3. Razina završenog obrazovanja:
a) osnovna škola
b) srednja škola
c) preddiplomski studij
d) diplomski studij
e) doktorski studij

4. Grad/mjesto porijekla:

5. Grad/mjesto koje ste napustili odlaskom u Irsku:

6. Je li Irska prva zemlja u koju ste emigrirali? DA/NE

7. Ako nije, molimo navedite zemlju/e u koju/e ste emigrirali prije dolaska u Irsku. Navedite i trajanje te/tih emigracija.

8. Grad/mjesto u koje ste emigrirali u Irskoj:

9. Koliko ste dugo u Irskoj?

10. Jeste li u Irsku otišli sami ili s obitelji?
a) $\operatorname{sam}(a)$
b) s obitelji

II

11. U kojoj se mjeri slažete s navedenim tvrdnjama:

1- Uopće se ne slažem. 2 - Ne slažem se. 3 - Niti se slažem, niti se ne slažem. 4 -Slažem se. 5 - U potpunosti se slažem.

\begin{tabular}{llllll}
\hline 1. Irci su gostoljubiv narod. & 1 & 2 & 3 & 4 & 5 \\
2. U Irskoj se dobro osjećam. & 1 & 2 & 3 & 4 & 5 \\
3. Želim dobro naučiti engleski jezik. & 1 & 2 & 3 & 4 & 5 \\
4. Engleski jezik je težak. & 1 & 2 & 3 & 4 & 5 \\
5. Nedostaje mi Hrvatska. & 1 & 2 & 3 & 4 & 5 \\
6. Nedostaje mi komunikacija na hrvatskom jeziku. & 1 & 2 & 3 & 4 & 5 \\
7. Planiram ostati u Irskoj. & 1 & 2 & 3 & 4 & 5 \\
8. Planiram se vratiti u Hrvatsku. & 1 & 2 & 3 & 4 & 5 \\
\hline
\end{tabular}

III

12. Koliko godina formalno (u sklopu obrazovnih institucija) učite engleski jezik? 
13. Molimo Vas da navedete u kojima ste od sljedećih obrazovnih institucija učili engleski jezik:

a) u osnovnoj školi

b) u srednjoj školi

c) na fakultetu

14. Jeste li se prije odlaska u Irsku koristili engleskim jezikom? DA/NE

15. Ako je Vaš odgovor na prethodno pitanje potvrdan, molimo Vas da navedete $u$ kojoj se mjeri slažete sa sljedećim tvrdnjama.

1 - Uopće se ne slažem. 2 - Ne slažem se. 3 - Niti se slažem, niti se ne slažem. 4 Slažem se. 5 - U potpunosti se slažem.

\begin{tabular}{|c|c|c|c|c|c|}
\hline $\begin{array}{l}\text { 1. U Hrvatskoj sam se engleskim najviše služio/ } \\
\text { služila u razgovoru s prijateljima. }\end{array}$ & 1 & 2 & 3 & 4 & 5 \\
\hline $\begin{array}{l}\text { 2. U Hrvatskoj sam se engleskim najviše služio/ } \\
\text { služila u razgovoru s obitelji. }\end{array}$ & 1 & 2 & 3 & 4 & 5 \\
\hline $\begin{array}{l}\text { 3. U Hrvatskoj sam se engleskim najviše služio/služila } \\
\text { u obrazovnim ustanovama (u školi ili na fakultetu). }\end{array}$ & 1 & 2 & 3 & 4 & 5 \\
\hline $\begin{array}{l}\text { 4. U Hrvatskoj sam se engleskim najviše služio/ } \\
\text { služila na radnom mjestu. }\end{array}$ & 1 & 2 & 3 & 4 & 5 \\
\hline $\begin{array}{l}\text { 5. U Hrvatskoj sam se engleskim najviše služio/ } \\
\text { služila u razgovoru sa strancima. }\end{array}$ & 1 & 2 & 3 & 4 & 5 \\
\hline $\begin{array}{l}\text { 6. U Hrvatskoj sam se engleskim najviše služio/ } \\
\text { služila na društvenim mrežama. }\end{array}$ & 1 & 2 & 3 & 4 & 5 \\
\hline
\end{tabular}

16. Molimo Vas da procijenite svoje znanje engleskog jezika prije dolaska u Irsku.

1- mnogo lošije od prosjeka

2- lošije od prosjeka

3- prosječno

4- bolje od prosjeka

5- mnogo bolje od prosjeka

17. Je li Vam pružena pomoć s engleskim prilikom dolaska u Irsku? DA/NE

18. Jeste li sami tražili neku pomoć s engleskom jezikom ili Vam je pomoć sama pružena?

a) Sam/a sam tražio/la pomoć.

b) Pružili su mi pomoć s engleskim jezikom.

19. Ukoliko ste ju dobili, molimo Vas da navedete kakva Vam je točno pomoć bila pružena (npr. tečajevi, osobna pomoć prijatelja Iraca ili Hrvata):

20. Molimo Vas da procijenite svoje znanje engleskog jezika danas.

1- mnogo lošije od prosjeka

2- lošije od prosjeka

3- prosječno

4- bolje od prosjeka

5- mnogo bolje od prosjeka 
21. Gdje radite?

22. Molimo Vas da navedete u kojoj se mjeri slažete sa sljedećim tvrdnjama:

1- Uopće se ne slažem. 2 - Ne slažem se. 3 - Niti se slažem, niti se ne slažem. 4 Slažem se. 5 - U potpunosti se slažem.

\begin{tabular}{llllll}
\hline $\begin{array}{l}\text { 1. U Irskoj je moguće naći posao bez ikakvog } \\
\text { znanja engleskog jezika. }\end{array}$ & 1 & 2 & 3 & 4 & 5 \\
$\begin{array}{l}\text { 2. Prilikom mog zapošljavanja poslodavcu je bilo } \\
\text { bitno moje znanje engleskog jezika. }\end{array}$ & 1 & 2 & 3 & 4 & 5 \\
$\begin{array}{l}\text { 3. Na radnom sam mjestu obvezan govoriti } \\
\text { engleski jezik. }\end{array}$ & 1 & 2 & 3 & 4 & 5 \\
$\begin{array}{l}\text { 4. Na radnom sam mjestu unaprijedio/unaprijedila } \\
\text { znanje engleskog jezika. }\end{array}$ & 1 & 2 & 3 & 4 & 5 \\
\hline
\end{tabular}

23. U kojoj se mjeri koristite engleskim jezikom na radnom mjestu?

1-nikada, 2-rijetko, 3-povremeno, 4-često, 5-vrlo često

24. S kim se najviše družite u Irskoj?
a) S Ircima.
b) S Hrvatima.
c) S pripadnicima drugih nacionalnosti.

25. Ako se družite s pripadnicima drugih nacionalnosti, navedite koje su:

26. Ako se najviše družite s Hrvatima, molimo Vas da odgovorite u kojoj se mjeri slažete s navedenim tvrdnjama:

1- Uopće se ne slažem. 2 - Ne slažem se. 3 - Niti se slažem, niti se ne slažem. 4 Slažem se. 5 - U potpunosti se slažem.

\begin{tabular}{llllll}
\hline $\begin{array}{l}\text { 1. Najviše se družim s Hrvatima jer ne znam } \\
\text { engleski jezik. }\end{array}$ & 1 & 2 & 3 & 4 & 5 \\
$\begin{array}{l}\text { 2. Najviše se družim s Hrvatima jer se sramim } \\
\text { svog znanja engleskog jezika. }\end{array}$ & 1 & 2 & 3 & 4 & 5 \\
$\begin{array}{l}\text { 3. Jedino me Hrvati u potpunosti razumiju pa se } \\
\text { zato s njima i najviše družim. }\end{array}$ & 1 & 2 & 3 & 4 & 5 \\
$\begin{array}{l}\text { 4. Najviše se družim s Hrvatima jer mi njihov } \\
\text { mentalitet najviše odgovara. }\end{array}$ & 1 & 2 & 3 & 4 & 5 \\
$\begin{array}{l}\text { 5. Najviše se družim s Hrvatima jer tako } \\
\text { umanjujem svoju nostalgiju za domom i }\end{array}$ & & & & & \\
materinskim jezikom. & 1 & 2 & 3 & 4 & 5 \\
\hline
\end{tabular}

IV

Molimo da na sljedeća pitanja odgovorite samo ako imate djecu.

27. Koliko imate djece? Koliko imaju godina?

28. S kim se Vaša djeca najviše druže?
a) $S$ Ircima.
b) S Hrvatima.
c) S pripadnicima drugih nacionalnosti. 
29. Ako se druže s pripadnicima drugih nacionalnosti, navedite koje su:

30. Molimo Vas da odgovorite u kojoj se mjeri slažete s navedenim tvrdnjama:

1- Uopće se ne slažem. 2 - Ne slažem se. 3 - Niti se slažem, niti se ne slažem. 4 Slažem se. 5 - U potpunosti se slažem.

1. Moja djeca moraju znati hrvatski jezik.

2. Moja se djeca najviše druže s Hrvatima jer tako rade na očuvanju hrvatskog jezika.

3. Moja se djeca najviše druže s Hrvatima jer je bitno u stranome svijetu održavati veze s ljudima iz svoje zemlje.

4. Moja djeca žele govoriti hrvatski jezik.

5. Mojoj je djeci hrvatski jezik teži od engleskoga.

6. Moja djeca više vole engleski nego hrvatski jezik.

7. Potičem svoju djecu da se druže s Ircima jer će tako brže i bolje naučiti engleski jezik.

8. Moja mi djeca pomažu s engleskim jezikom. $\begin{array}{lllll}1 & 2 & 3 & 4 & 5\end{array}$

$\begin{array}{lllll}1 & 2 & 3 & 4 & 5\end{array}$

$\begin{array}{lllll}1 & 2 & 3 & 4 & 5\end{array}$

$\begin{array}{lllll}1 & 2 & 3 & 4 & 5\end{array}$

$\begin{array}{lllll}1 & 2 & 3 & 4 & 5\end{array}$

$\begin{array}{lllll}1 & 2 & 3 & 4 & 5\end{array}$

$\begin{array}{lllll}1 & 2 & 3 & 4 & 5\end{array}$

$\begin{array}{lllll}1 & 2 & 3 & 4 & 5\end{array}$ 


\title{
LANGUAGE USE AND ATTITUDES AMONG CROATIAN IMMIGRANTS IN IRELAND
}

\begin{abstract}
Immigration in Ireland, including the Croatian one, has risen significantly in recent times. That is why in the last several years Ireland has been trying to find ways of ensuring the adequate cultural and linguistic integration of immigrants into Irish society. This paper deals with the language use and attitudes among Croatian immigrants in Ireland. The research that was conducted in the period from June to August 2019 included 82 Croatian immigrants in Ireland. It included the application of a questionnaire that consisted of four parts and that was filled out by the participants through the Facebook social network. The participants were asked questions connected to their emigration to Ireland. Most of the language-related questions included a reference to the English language, with a focus on specific aspects related to the process of learning, knowledge and use of English in different contexts. The results of the research suggest, among other things, that most participants have a positive attitude towards residing in Ireland and towards the English language. Most of them evaluated their current knowledge of English as better than average. Although the knowledge of English was not predominantly evaluated as crucial for finding employment in Ireland, still a significant number of participants evaluated it as relevant for their employment.
\end{abstract}

Key words: immigration policy, language policy, language use, language attitudes, Croatian immigrants, Ireland, the English language 